\title{
PENGARUH LINGKUNGAN KERJA DAN DISIPLIN KERJA TERHADAP KINERJA PEGAWAI PADA KANTOR KECAMATAN BEKASI BARAT
}

\author{
Sunarno \\ Jurusan Perbankan Syariah \\ Universitas Islam As-Syafi'iyah \\ Sunarno1978@gmail.com
}

\begin{abstract}
Abtraksi
Tujuan penelitian ini menguji pengaruh lingkungan kerja dan disiplin kerja terhadap kinerja pegawai pada kantor Kecamatan Bekasi Barat. Sampel diambil sebanyak 40 pegawai dengan teknik pengumpulan data menggunakan kuesioner. Data dianalisis menggunakan regresi berganda. Hasil penelitian diperoleh bahwa ada pengaruh positif dan tidak signifikan antara lingkungan kerja terhadap kinerja pegawai, ada pengaruh positif dan signifikan antara disiplin kerja terhadap kinerja pegawai, dan secara bersamasama ada pengaruh positif dan signifikan antara lingkungan kerja dan disiplin kerja terhadap kinerja pegawai pada kantor Kecamatan Bekasi Barat. Hal ini menunjukkan bahwa semakin memadai lingkungan kerja dan semakin tinggi disiplin kerja yang dimiliki maka akan semakin tinggi kinerja yang diberikan.
\end{abstract}

Kata Kunci : Lingkungan Kerja, Disiplin Kerja, Kinerja Pegawai

\section{PENDAHULUAN}

Dalam sebuah organisasi atau instansi, manusia merupakan salah satu unsur terpenting. Tanpa peran manusia meskipun berbagai faktor yang dibutuhkan telah tersedia, organisasi atau instansi tidak akan berjalan. Perhatian organisasi yang lebih besar terhadap pengembangan dan peningkatan sumber daya manusia, beberapa waktu belakangan ini disebabkan karena kualitas sumber daya manusia menentukan dan menggambarkan kualitas dan kuantitas suatu organisasi atau instansi. Selain aspek pengembangan dan peningkatan sumber daya manusia, yang juga menjadi perhatian adalah penguasaan dan pemanfaatan teknologi. Menurut Syafri dan Alwi (2014:01) bahwa pada era globalisasi sekarang ini sumber daya manusia dalam administrasi publik semakin penting meskipun teknologi banyak menggantikan fungsi-fungsi pekerjaan manusia. Dalam administrasi publik teknologi hanya pendukung untuk memperlancar dan mempercepat pelaksaan pekerjaan manusia.

Dalam hal ini, semua organisasi dituntut untuk dapat membuat perencanaan yang sistematis yang bertujuan untuk meningkatkan kualitas dan kuantitas sumber daya yang dimilikinya terutama sumber daya manusianya. Manusia merupakan penggerak dan penentu jalannya suatu organisasi atau instansi. Efektifnya suatu organisasi atau instansi sangat tergantung pada baik buruknya pengembangan sumber daya itu sendiri. Bagi organisasi atau instansi pastinya mengharapkan sumber daya manusia yang dapat mencapai tujuan perusahaan secara efektif dan efisien tidak terkecuali untuk kantor Kecamatan Bekasi Barat.

Menurut Undang-undang Nomor 32 Tahun 2004 yaitu tentang Pemerintah Daerah bahwa kecamatan sebagai wilayah kerja Camat sebagai perangkat daerah kabupaten dan 
daerah kota. Perangkat Daerah kabupaten/kota terdiri dari sekretariat daerah, sekretariat DPRD, dinas daerah, lembaga teknis daerah, kecamatan dan kelurahan.

Kecamatan Bekasi Barat merupakan salah satu organisasi yang memegang peranan yang sangat penting dalam melaksanakan kebijakan-kebijakan pemerintah. Menurut Dwiyanto dkk (2017:54) birokrasi yang memiliki kinerja buruk dalam memberikan pelayanan kepada publik akan sangat mempengaruhi kinerja pemerintah dan masyarakat secara keseluruhan dalam rangka meningkatkan daya saing suatu negara. Menurut Dwiyanto dkk (2017:55) memburuknya kualitas birokrasi di Indonesia tersebut tercemin dari meningkatnya skor birokrasi dan "pita merah" dalam praktik birokrasi dibandingkan pada tahun sebelumnya. Meningkatnya skor birokrasi merupakan indikasi bahwa kinerja birokrasi di Indonesia semakin memburuk dan semakin korup. Dari kacamata iklim bisnis secara keseluruhan, dengan memperhatikan faktor sistemik, sosio-politik, lingkungan, pasar dan dinamika perekonomian.

Fasilitas pada kantor Kecamatan kondisi saat ini belum memadai. Para pegawai masih membutuhkan beberapa fasilitas yang dapat menunjang terutama untuk membantu dalam bekerja. Beberapa diantaranya seperti mesin pengganda atau mesin fotocopy, printer, wifi, lemari arsip dan tata ruang. Selama ini para pegawai kesulitan untuk bekerja secara efisien dan efektif dikarenakan fasilitas pada kantor Kecamatan Bekasi Barat masih harus diperbaiki. Sebagai beberapa contoh terkait dengan tata ruang pada kantor Kecamatan Bekasi Barat, tata ruang yang harus perlu diperbaiki. Sebab, ada beberapa ruangan yang belum tertata rapih dan perlu dibuatnya ruangan khusus seluruh arsip yang ada. Agar penyimpanan arsip tidak membingungkan saat diperlukan dan tidak mengganggu pegawai lain saat bekerja. Selanjutnya, dengan beberapa fasilitas atau alat bantu kerja yang harus ditambahkan. Salah satunya seperti mesin fotocopy, pegawai harus keluar kantor untuk memfotocopy beberapa berkas kantor.

Hal ini bisa terjadinya ketidakdisiplinan para pegawai, bagi pegawai yang masih melanggar peraturan dalam jam bekerja setelah usai memfotocopy berkas. Selanjutnya, terkait dengan masalah tupoksi (tugas pokok dan fungsi) yang telah dibebankan kepada para pegawai khususnya dalam tata usaha pada kantor Kecamatan Bekasi Barat yang sampai saat ini masih perlu perbaikan. Yaitu masalah penanganan website dan pengaturan masalah pertimbangan / surat keterangan, izin dan/atau jasa pelayanan publik yang telah akan dikeluarkan Kecamatan. Pada masalah penanganan website memungkinkan perlunya tenaga ahli yang dapat menangani penggunaan website guna menjalankan tugas dan fungsi yang diberikan sekaligus membantu masyarakat untuk mengakses informasi yang akurat dari kantor Kecamatan Bekasi Barat. Dan pada bagian pengaturan surat keterangan, izin atau jasa pelayanan publik seharusnya bisa lebih cepat dalam pengurusan atau proses agar tidak banyak mengulur waktu. Sehingga masyarakat yang membutuhkan berkas atau administrasi publik cepat terselesaikan urusannya.

Pada kantor Kecamatan Bekasi Barat menyadari bahwa dengan kurangnya perhatian terhadap lingkungan kerja dan rendahnya disiplin kerja pegawai maka akan berakibat menurunnya kinerja pegawai. Dengan melalui atau memperbaiki lingkungan kerja dan menerapkan sistem disiplin kerja yang baik, pegawai akan mampu dan optimal dalam bekerja serta meningkatkan kinerja pegawai. Dilihat dari permasalahan yang ada di lapangan maka penulis mengajukan judul penelitian yaitu :"Pengaruh lingkungan kerja dan disiplin kerja terhadap kinerja pegawai pada kantor Kecamatan Bekasi Barat”. 


\section{LANDASAN TEORI}

Sebuah organisasi atau perusahaan dalam mengatur sumber daya manusia perlu adanya manajemen yang baik agar semua kegiatan dapat berjalan dengan lancar dan sesuai dengan apa yang diinginkan. Didalam perusahaan, manajemen menjadikkan sumber daya manusia (SDM) sebagai salah satu indikator penting dalam pencapaian tujuan organisasi. Sumber daya manusia merupakan aset organisasi yang sangat vital. Peran dan fungsinya tidak dapat digantikan oleh sumber daya lain.

Lingkungan kerja merupakan bagian komponen yang sangat penting ketika pegawai melakukan aktivitas bekerja. Pegawai akan mampu melaksanakan kegiatannya dengan baik dan memadai apabila pegawai dapat melaksanakan kegiatannya secara optimal, sehat, aman dan nyaman. Keadaan lingkungan kerja yang kurang baik dapat menuntut tenaga dan waktu yang lebih banyak dan menjadikan pekerjaan yang tidak efisien. Lingkungan kerja yang baik dan memadai juga dapat mendorong pegawai untuk menghasilkan kinerja yang lebih baik, sebaliknya apabila lingkungan kerja tidak memadai dapat menurunkan kinerja pegawai.

Dalam sebuah organisasi, lingkungan kerja yang memadai sangat diperhatikan dengan serius, hal ini disebabkan lingkungan kerja menjadi salah satu faktor yang mempengaruhi kinerja seseorang, lingkungan kerja yang baik akan memberikan rasa aman dan nyaman terhadap pegawai, sehingga akan timbul semangat kerja dan kegairah kerja pegawai melaksanakan pekerjaannya.

Dalam kehidupan organisasi atau instansi, akan sangat banyak ketaatan dan peraturan serta ketentuan yang ditetapkan pada perusahaan tersebut. Dengan kata lain perusahaan sangat membutuhkan disiplin kerja, karena dengan disiplin kerja apa yang diinginkan dan yang menjadi tujuan organisasi atau instansi akan tercapai. Akan tetapi sebaliknya apabila disiplin kerja tidak ditegakan atau tidak dijalankan oleh semua karyawan maka tuntutan perusahaan susah akan didapat.

Untuk meningkatkan kinerja pegawai pada perusahaan atau instansi perlu memperhatikan mengenai masalah lingkungan kerja. Lingkungan kerja merupakan suatu keadaan yang terdapat disekitar tempat kerja yang akan mempengaruhi pegawai baik secara langsung maupun secara tidak langsung serta berpengaruh besar terhadap kinerja pegawai. Lingkungan kerja yang baik akan memberikan rasa aman dan nyaman terhadap pegawai sehingga timbul rasa semangat dan gairah kerja pegawai yang dapat menghasilkan kinerja yang baik. Disiplin kerja merupakan perbuatan tingkah laku perorangan, kelompok atau masyarakat berupa kepatuhan atau ketaatan terhadap peraturan, ketentuan, etika, norma, dan kaidah yang berlaku yang dibuat sehingga dapat memberikan kinerja yang baik untuk perusahaan atau instansi. Berdasarkan pemikiran di atas, maka lingkungan kerja dan disiplin kerja dapat dapat terlihat hubungan antara lingkungan kerja dan disiplin kerja terhadap kinerja pegawai, sehingga dapat dibuat kerangka pemikiran seperti gambar dibawah ini. 


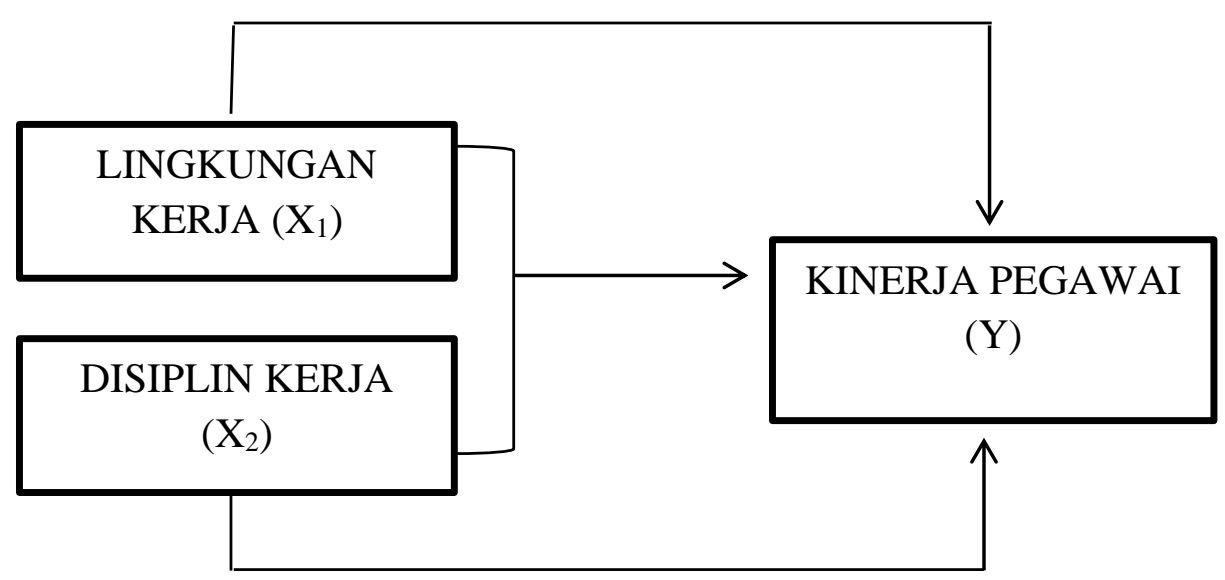

$\mathrm{H}_{1}$ : Lingkungan kerja $\left(\mathrm{X}_{1}\right)$ berpengaruh terhadap kinerja $(\mathrm{Y})$

$\mathrm{H}_{2}$ : Disiplin kerja $\left(\mathrm{X}_{2}\right)$ berpengaruh terhadap kinerja $(\mathrm{Y})$

$\mathrm{H}_{3}$ : Lingkungan kerja $\left(\mathrm{X}_{1}\right)$ dan disiplin kerja $\left(\mathrm{X}_{2}\right)$ berpengaruh terhadap kinerja (Y)

\section{METODOLOGI PENELITIAN}

Dengan skala likert, maka variabel yang akan diukur dijabarkan menjadi indikator variabel. Kemudian indikator tersebut dijadikan sebagai titik tolak ukur untuk menyusun item-item instrumen yang dapat berupa pernyataan atau pertanyaan.

Definisi operasional adalah informasi ilmiah yang sangat membantu penelitian lain yang ingin melakukan penelitian dengan menggunakan variabel yang sama. Berdasarkan informasi ini kita akan mengetahui bagaimana cara melakukan pengukuran terhadap variabel yang dibangun berdasarkan konsep yang sama.

Dalam penggunaan analisis korelasi agar menunjukkan hubungan yang valid atau tidak biada maka perlu pengujian asumsi klasik pada model regresi. Adapun asumsi dasar yang harus dipenuhi antara lain :

Uji Normalitas

Menurut Noor (2015:47) uji normalitas untuk menguji distribusi data yang akan dianalisis menyebar normal. Uji normalitas dimaksudkan untuk menguji apakah data yang digunakan dalam penelitian memiliki distrbusi normal baik secara multivariat maupun univariat.

Evaluasi normalitas dilakukan dengan menggunakan kriteria critical ratio skweness value sebesar $\pm 2,58$ pada tingkat signifikansi $99 \%$. Data mempunyai distribusi normal jika jika nilai ctitical ratioo (c.r) skweness di bawah harga mutlak \pm 2,85 . Uji normalitas menggunakan metode univariate normality dengan dengan melihat koefisien indeks skew univariate dan indeks kurtosis multiunivariate berada di antara 0 sampai $\pm 2,58$.

Uji normalitas data untuk memperlihatkan bahwa data sampel berasal dari populasi yang berdistribusi normal. Teknik yang digunakan Kolmogorov-Smirnov dan uji Probability Plot dengan SPSS. 


\section{PEMBAHASAN DAN HASIL PENELITIAN}

Kecamatan Bekasi Barat merupakan bagian dari wilayah Kota Bekasi, terletak di sebelah barat Kota Bekasi yang geografis berbatasan langusng dengan Ibu Kota Jakarta dan perkembangannya telah menunjukkan kemajuan di berbagai bidang sesuai dengan peran dan fungsinya. Luas wilayah Kecamatan Bekasi Barat adalah 1.492,712 Ha. Kantor Kecamatan Bekasi Barat berlokasi di Jl. Raya Bintara No. 4 Kota Bekasi. Dan terdiri dari lima Kelurahan yaitu : Kelurahan Bintara Jaya, Kelurahan Bintara, Kelurahan Kranji, Kelurahan Kota Baru, Kelurahan Jakasampurna. Kantor Kecamatan Bekasi Barat ini berada di tengah-tengah area yang strategis yaitu berdekatan dengan stasiun kereta api cakung dan terminal bus terbesar yaitu terminal pulogebang. Selain itu banyaknya kendaraan umum yang memudahkan lalu lalang untuk tujuan sampai kemana saja.

Kantor Kecamatan Bekasi Barat memiliki visi yaitu "Bekasi Barat Menuju Masyarakat Yang Sejahtera dan Bernuansa Ihsan". Selain itu juga kantor Kecamatan Bekasi Barat memiliki misi, yakni :

1. Menumbuhkembangkan peran aktif dalam mendukung pembangunan;

2. Mewujudkan peran aktif aparat dan masyarakat yang cerdas dan lingkungan yang sehat;

3. Mewujudkan pemerintahan yang profesional, akuntable dan efesien;

4. Memberdayakan ekonomi masyarakat melalui pengembangan UMKM dan program pelatihanusaha kerja mandiri.

5. Mengembangkan sistem kehidupan masyakat yang aman,tentram dan damai

\section{Hasil Uji Validitas}

Menurut Sujarweni (2015:160) uji validitas digunakan untuk mengetahui kelayakan butir-butir dalam suatu daftar pertanyaan dalam mendefinisikan suatu variabel. Hasil $r$ hitung kita bandingkan dengan $r$ tabel dimana $\mathrm{df}=\mathrm{n}-2$ dengan sig 5\%. Jika $\mathrm{r}$ tabel $<\mathrm{r}$ hitung maka valid. Uji validitas menggunakan teknik korelasi Product Moment. Uji validitas digunakan untuk mengukur valid atau tidaknya suatu kuesioner. Kuesioner dikatakan valid jika butir pada pertanyaan pada kuesioner mampu untuk mengungkapkan sesuatu yang akan diukur oleh kuesioner tersebut.

Menurut Sugiyono (2016:183) kriteria apabila $r_{\text {hitung }}>r_{\text {table }}$ (pada taraf signifikan $5 \%$ ), maka dapat dikatakan item kuesioner tersebut valid. Apabila $r$ hitung $>r_{\text {table }}$ (pada taraf signifikan 5\%), maka dapat dikatakan item kuesioner tersebut tidak valid. $r$ hitung dibandingkan dengan $r$ tabel dimana :

$\mathrm{df}=\mathrm{n}-2$

$=45-2$

$=43$ dengan signifikan 5\%, maka besar $\mathrm{r}$ tabel = 0,304.

Maka, suatu item pertanyaan dikatakan valid jika $r$ hitung $>r$ tabel. Dan jika $r$ hitung $<$ r tabel maka tidak valid.

1) Hasil uji validitas instrumen penelitian untuk variabel lingkungan kerja 
Hasil uji validitas Lingkungan Kerja $\left(\mathrm{X}_{1}\right)$

\begin{tabular}{|c|c|c|c|}
\hline Pertanyaan & $\begin{array}{c}\mathbf{r} \\
\text { hitung }\end{array}$ & $\mathbf{r}$ tabel & keterangan \\
\hline $\mathrm{X} 1$ & 0,406 & 0,304 & valid \\
\hline $\mathrm{X} 2$ & 0,446 & 0,304 & valid \\
\hline $\mathrm{X} 3$ & 0,696 & 0,304 & valid \\
\hline X4 & 0,618 & 0,304 & valid \\
\hline X5 & 0,515 & 0,304 & valid \\
\hline X6 & 0,536 & 0,304 & valid \\
\hline X7 & 0,364 & 0,304 & valid \\
\hline X8 & 0,492 & 0,304 & valid \\
\hline X9 & 0,606 & 0,304 & valid \\
\hline X10 & 0,406 & 0,304 & valid \\
\hline
\end{tabular}

Sumber : Hasil pengolahan SPSS 24, 2018

Berdasarkan table diatas diketahui bahwa $\mathrm{r}$ hitung pada variabel lingkungan kerja $\left(\mathrm{X}_{1}\right)$ lebih besar dari $\mathrm{r}$ tabel $=0,304$. Dengan demikian dapat disimpulkan semua butir pertanyaan (kuesioner) pada variabel lingkungan kerja adalah valid. Sehingga 10 butir pertanyaan (kuesioner) lingkungan kerja tersebut dapat dijadikan sebagai bahan instrumen untuk melakukan penelitian.

2) Hasil uji validitas instrumen penelitian untuk variabel disiplin kerja

Hasil uji validitas Disiplin Kerja $\left(\mathrm{X}_{2}\right)$

\begin{tabular}{|c|c|c|c|}
\hline Pertanyaan & $\boldsymbol{r}$ hitung & $\boldsymbol{r}$ tabel & keterangan \\
\hline $\mathrm{X} 1$ & 0,414 & 0,304 & valid \\
\hline $\mathrm{X} 2$ & 0,655 & 0,304 & valid \\
\hline $\mathrm{X} 3$ & 0,401 & 0,304 & valid \\
\hline X4 & 0,459 & 0,304 & valid \\
\hline X5 & 0,425 & 0,304 & valid \\
\hline X6 & 0,735 & 0,304 & valid \\
\hline X7 & 0,538 & 0,304 & valid \\
\hline X8 & 0,598 & 0,304 & valid \\
\hline X9 & 0,434 & 0,304 & valid \\
\hline X10 & 0,525 & 0,304 & valid \\
\hline
\end{tabular}

Sumber : Hasil pengolahan SPSS 24, 2018

Berdasarkan table diatas diketahui bahwa $r$ hitung pada disiplin kerja $\left(\mathrm{X}_{2}\right)$ lebih besar dari $\mathrm{r}$ tabel $=0,304$. Dengan demikian dapat disimpulkan semua butir pertanyaan (kuesioner) pada variabel disiplin kerja adalah valid. Sehingga 10 butir pertanyaan (kuesioner) disiplin kerja tersebut dapat dijadikan sebagai bahan instrumen untuk melakukan penelitian.

3) Hasil uji validitas instrumen penelitian untuk variabel kinerja pegawai Hasil uji validitas Kinerja Pegawai (Y) 


\begin{tabular}{|c|c|c|c|}
\hline Pertanyaan & $\boldsymbol{r}$ hitung & $\boldsymbol{r}$ tabel & keterangan \\
\hline Y1 & 0,327 & 0,304 & valid \\
\hline Y2 & 0,368 & 0,304 & valid \\
\hline Y3 & 0,433 & 0,304 & valid \\
\hline Y4 & 0,386 & 0,304 & valid \\
\hline Y5 & 0,379 & 0,304 & valid \\
\hline Y6 & 0,326 & 0,304 & valid \\
\hline Y7 & 0,553 & 0,304 & valid \\
\hline Y8 & 0,484 & 0,304 & valid \\
\hline Y9 & 0,347 & 0,304 & valid \\
\hline Y10 & 0,414 & 0,304 & valid \\
\hline
\end{tabular}

Sumber : Hasil pengolahan SPSS 24, 2018

Berdasarkan table diatas diketahui bahwa $r$ hitung pada variabel kinerja Pegawai (Y) lebih besar dari $r$ tabel $=0,304$. Dengan demikian dapat disimpulkan semua butir pertanyaan (kuesioner) pada variabel kinerja pegawai adalah valid. Sehingga 10 butir pertanyaan (kuesioner) kinerja pegawai tersebut dapat dijadikan sebagai bahan instrumen untuk melakukan penelitian.

\section{Hasil Uji Reliabilitas}

Munurut Noor (2014:24) reliabilitas (keandalan) pengukuran dengan menggunakan Alfa Cronbach adalah koefisien keandalan yang menunjukan seberapa baiknya item/butir dalam suatu kumpulan secara positif berkolerasi satu sama lain. Tentang uji realibilitas ini dapat disampaikan hal-hal pokoknya atau kriteria, sebagai berikut :

1) Untuk menilai kestabilan ukuran dan konsistensi responden dalam menjawab kuesioner. Kuesioner tersebut mencerminkan konstruk sebagai dimensi suatu variabel yang disusun dalam bentuk pertanyaan.

2) Uji realibilitas dilakukan secara bersama-sama terhadap seluruh pertanyaan.

3) Jika nilai alpha $>0,60$, disebut relible

4)

Hasil uji reliabilitas instrumen penelitian dapat dilihat pada :

\begin{tabular}{|c|c|c|}
\hline Variabel & Nilai Alpha Cronbach's & Keterangan \\
\hline $\mathbf{X}_{\mathbf{1}}$ & 0,604 & Reliabel \\
\hline $\mathbf{X}_{\mathbf{2}}$ & 0,724 & Reliabel \\
\hline $\mathbf{Y}$ & 0,448 & Reliabel \\
\hline
\end{tabular}

Sumber : Hasil pengolahan SPSS 24, 2018

Pada tabel diatas diketahui bahwa nilai $\mathrm{r}$ alpha positif lebih besar dari nilai 0,60 $(0 .>0,60)$. Dengan demikian kuesioner pada variabel lingkungan kerja, disiplin kerja dan kinerja pegawai dapat dikatakan reliabel dan dapat digunakan sebagai instrumen penelitian. 


\section{Analisis Regresi}

Analisis regresi linier sederhana

Analisis regresi linear sederhana dalam penelitian ini digunakan untuk mengetahui pengaruh variabel bebas lingkungan kerja (X1) dan disiplin kerja (X2) terhadap variabel terikat kinerja pegawai (Y). untuk pengujian hipotesis 1 dan 2 secara parsial maka dilakukan uji coba regresi secara sederhana.

Hasil uji regresi sederhana lingkungan kerja

\begin{tabular}{|l|r|r|r|}
\hline \multicolumn{4}{|c|}{ Nilai regresi sederhana } \\
\hline & $\begin{array}{c}\text { Unstandardized } \\
\text { Coefficients }\end{array}$ & $\mathrm{T}$ & \multicolumn{1}{c|}{ Sig. } \\
\cline { 2 - 4 } Variabel / Konstanta & $\mathrm{B}$ & & \\
\hline (Constant) & 21,599 & 2,600 & 0,011 \\
\hline lingkungan kerja & 0,469 & 2,402 & 0,018 \\
\hline
\end{tabular}

Sumber : Hasil pengolahan SPSS 24, 2018

Berdasarkan tabel diatas hasil analisis regresi sederhana antara $\mathrm{X}_{1}$ dan $\mathrm{Y}$ didapatkan persamaan regresi.

$$
\begin{aligned}
& Y=a+b X_{1} \\
& Y=21,599+0,469 X_{1}
\end{aligned}
$$

Dari persamaan di atas dapat dijelaskan sebagai berikut.

Nilai a $=21,599$, artinya jika tidak ada perubahan dari variabel lingkungan kerja, maka kinerja pegawai memiliki skor 21,599.

Nilai $b=0,469$, artinya setiap penambahan satu skor atau nilai pada lingkungan kerja maka kinerja pegawai akan mengalami peningkatan sebesar skor 0,469.

Analisis regresi linier sederhana $\mathrm{X}_{2}$ dan

Hasil analisis regresi linier sederhana disiplin kerja

\begin{tabular}{|l|r|r|r|}
\hline \multirow{2}{*}{ Variabel / Konstanta } & $\begin{array}{c}\text { Unstandardized } \\
\text { Coefficients }\end{array}$ & $\mathrm{T}$ & \multicolumn{1}{c|}{ Sig. } \\
\cline { 2 - 4 } & \multicolumn{1}{|c|}{$\mathrm{B}$} & & \\
\hline (Constant) & 18,848 & 5,466 & 0,000 \\
\hline disiplin kerja & 0,538 & 6,600 & 0,000 \\
\hline
\end{tabular}

Sumber : Hasil pengolahan SPSS 24, 2018

Berdasarkan tabel 4.43 hasil analisis regresi sederhana antara $\mathrm{X}_{2}$ dan $\mathrm{Y}$ didapatkan persamaan regresi.

$$
\begin{aligned}
& \mathrm{Y}=\mathrm{a}+\mathrm{bX}_{2} \\
& \mathrm{Y}=18,848+0,538 \mathrm{X}_{2}
\end{aligned}
$$

Dari persamaan di atas dapat dijelaskan sebagai berikut :

Nilai a $=18,848$, artinya jika tidak ada perubahan dari variabel disiplin kerja, maka kinerja pegawai adalah 18,848 . 
Nilai $b=0,538$, artinya setiap penambahan satu skor atau nilai pada disiplin kerja, maka skor kinerja pegawai akan mengalami peningkatan skor 0,538 .

Analisis regresi linier berganda antara $\mathrm{X}_{1}, \mathrm{X}_{2}$ dan $\mathrm{Y}$

Analisis Regresi Linier Berganda bermaksud meramalkan bagaimana keadaan (naik turunnya) variabel dependen (kriterium), bila dua atau lebih variabel independen sebagai faktor prediktor dimanipulasi (dinaik turunkan nilainya).

Hasil analisis regresi liniear berganda

\begin{tabular}{|l|r|c|c|c|}
\hline \multirow{2}{*}{ Variabel / Konstanta } & \multicolumn{2}{|c|}{$\begin{array}{c}\text { Unstandardized } \\
\text { Coefficients }\end{array}$} & & \multirow{2}{*}{} \\
\cline { 2 - 3 } & \multicolumn{1}{|c|}{ B } & $\begin{array}{c}\text { Std. } \\
\text { Error }\end{array}$ & \multicolumn{1}{c|}{ T } & \multirow{2}{*}{ Sig. } \\
\hline (Constant) & 13,283 & 7,134 & 1,862 & 0,066 \\
\hline lingkungan kerja & 0,154 & 0,173 & 0,891 & 0,375 \\
\hline disiplin kerja & 0,515 & 0,086 & 6,010 & 0,000 \\
\hline
\end{tabular}

Sumber : Hasil pengolahan SPSS 24, 2018

Berdasarkan table tersebut hasil analisis regresi linier sederhana antara $\mathrm{X}_{1}, \mathrm{X}_{2}$ dan $\mathrm{Y}$ didapatkan persamaan regresi

$$
\mathrm{Y}=13,283+0,154 \mathrm{X}_{1}+0,515 \mathrm{X}_{2}
$$

Dilihat $\mathrm{Y}$ adalah kinerja pegawai, $\mathrm{X}_{1}$ adalah lingkungan kerja dan $\mathrm{X}_{2}$ adalah disiplin kerja. Berdasarkan persamaan pada tabel tersebut dapat disimpulkan hasil uji secara partial dan simultan sebagai berikut :

Berdasarkan persamaan regresi berganda $\mathrm{Y}=13,283+0,154 \mathrm{X}_{1}+0,515 \mathrm{X}_{2}$ dapat dijelaskan bahwa

1) Nilai a $=13,283$, artinya jika tidak ada perubahan dari variabel lingkungan kerja dan disiplin kerja, maka skor dari kinerja pegawai adalah 13,283.

2) Nilai $b_{1}=0,154$, artinya setiap penambahan skor pada lingkungan kerja, maka kinerja akan mengalami peningkatan skor sebesar 0,154 pada saat disiplin kerja $\left(\mathrm{X}_{2}\right)=0$

3) nilai $b_{2}=0,515$, artinya setiap penambahan satu skor lingkungan kerja, maka kinerja pegawai akan mengalami peningkatan skor sebesar 0,515 pada saat lingkungan kerja $\left(\mathrm{X}_{1}\right)=0$.

Hal ini menunjukkan bahwa terdapat pengaruh positif dan signifikan antara lingkungan kerja dan disiplin kerja terhadap kinerja pegawai pada kantor Kecamatan Bekasi Barat.

\section{Analisis Korelasi}

Teknik korelasi ini digunakan untuk mengukur tingkat asosiasi atau hubungan antara variabel bebas $(\mathrm{X})$ dengan variabel terikat $(\mathrm{Y})$ melalui koefisien korelasi yang disimbolkan dengan huruf (r)".

1) Analisis Korelasi Sederhana 
Hasil korelasi sederhana

\begin{tabular}{|c|c|c|c|c|}
\hline \multicolumn{5}{|c|}{ Correlations } \\
\hline & & lingkungan kerja & disiplin kerja & kinerja pegawai \\
\hline \multirow[t]{3}{*}{ lingkungan kerja } & Pearson Correlation & 1 & $0,304^{* *}$ & $0,251^{*}$ \\
\hline & Sig. (2-tailed) & & 0,004 & 0,018 \\
\hline & $\mathrm{N}$ & 88 & 88 & 88 \\
\hline \multirow[t]{3}{*}{ disiplin kerja } & Pearson Correlation & $0,304^{* * *}$ & 1 & $0,580^{* * *}$ \\
\hline & Sig. (2-tailed) & 0,004 & & 0,000 \\
\hline & $\mathrm{N}$ & 88 & 88 & 88 \\
\hline \multirow[t]{3}{*}{ kinerja pegawai } & Pearson Correlation & $0,251^{*}$ & $0,580^{* *}$ & 1 \\
\hline & Sig. (2-tailed) & 0,018 & 0,000 & \\
\hline & $\mathrm{N}$ & 88 & 88 & 88 \\
\hline
\end{tabular}

Sumber : Hasil pengolahan SPSS 24, 2018

Berdasarkan tabel tersebut dapat diketahui bahwa hubungan lingkungan kerja dengan kinerja pegawai memiliki nilai 0,251. Hal ini dapat disimpulkan bahwa variabel lingkungan kerja $\left(\mathrm{X}_{1}\right)$ dengan kinerja pegawai $(\mathrm{Y})$ memiliki tingkat kekuatan hubungan yang positif rendah. Sedangkan nilai korelasi variabel disiplin kerja $\left(\mathrm{X}_{2}\right)$ dengan kinerja pegawai (Y) memiliki nilai 0,580 . Hal ini dapat disimpulkan bahwa variabel disiplin $\left(\mathrm{X}_{2}\right)$ dengan kinerja pegawai (Y) memiliki tingkat kekuatan hubungan yang positif sedang.

2) Analisis korelasi berganda dan koefisien determinasi

Analisis korelasi berganda digunakan untuk mengetahui derajat atau kekuatan hubungan antara seluruh variabel X terhadap variabel Y secara bersamaan. Adapun, koefisien determinasi digunakan untuk mengetahui seberapa besar presentase pengaruh langsung variabel bebas yang semakin dekat hubungannya dengan variabel terikat.

Berdasarkan data tersebut diketahui menunjukkan hubungan lingkungan kerja dan disiplin kerja terhadap kinerja pegawai memiliki koefisien korelasi sebesar 0,585. Hal ini diartikan bahwa variabel $\mathrm{X}_{1}$ dan $\mathrm{X}_{2}$ dengan $\mathrm{Y}$ memiliki tingkat hubungan yang positif dan sedang. Koefisien determinasi lingkungan kerja dan disiplin kerja terhadap kinerja pegawai sebesar 0,342 atau 34,2\%. Artinya bahwa 34,2\% kinerja pegawai pada kantor Kecamatan Bekasi Barat ditentukan oleh lingkungan kerja dan disiplin. Sedangkan sisanya yakni 65,8\% dipengaruhi oleh faktor lain yang tidak diteliti pada penelitian ini.

\section{Pembahasan}

\section{Pengaruh lingkungan kerja terhadap kinerja pegawai}

Berdasarkan hasil analisis pengujian hipotesis menunjukkan bahwa lingkungan kerja berpengaruh dan tidak signifikan terhadap kinerja pegawai. Hal ini menunjukkan lingkungan kerja pada kantor Kecamatan Bekasi Barat beberapa sudah memadai dan meskipun beberapa pegawai beranggapan bahwa lingkungan kerja belum terlalu memadai dan perlu perbaikkan tetapi hal ini tidak telalu dipersoalkan untuk masalah lingkungan kerja khususnya fasilitas yang berupa fisik, pegawai pun merasa baik dan tetap masih bisa bekerja dengan nyaman walaupun masih ada fasilitas kantor yang 
kurang memadai. Dari hal ini menunjukkan bahwa ada faktor lain yang mempengaruhi selain dari variabel yang diteliti.

Berdasarkan persepsi responden terhadap pernyataan yang memiliki skor jawaban tertinggi dibandingkan dengan pernyataan-pertanyaan lainnya yang digunakan untuk menggambarkan variabel lingkungan kerja yaitu hubungan yang harmonis antar pegawai. Karena sebagian pegawai beranggapan bahwa rekan sepekerjanya adalah salah satu keluarga yang sama-sama bekerja dengan instansi yang sama. Tidak ada senioritas atau junioritas dalam bekerja. Hal ini menunjukkan bahwa pegawai kantor Kecamatan Bekasi Barat memiliki hubungan yang baik antar/sesama pegawai. Dimana para pegawai bisa saling menciptakan keharmonisan antar pegawai beberapa diantaranya yaitu sikap saling menghargai, komunikasi yang baik dan lainlain. Demikian pada persepsi bahwa area kantor strategis. Penyataan ini sesuai apa yang ada pada kondisi kantor Kecamatan Bekasi Barat bahwa area kantor sudah strategis sehingga memudahkan pegawai untuk bekerja. Karena area pada kantor Kecamatan Bekasi Barat berada di tengah-tengah yaitu berdekatan dengan stasiun kereta, terminal bus dan beberapa kendaraan angkutan umum untuk menuju lokasi tersebut. Sehingga hal ini dapat memudahkan pegawai untuk bekerja bagi pegawai yang belum memiliki kendaraan pribadi atau menjadi sebuah alternatif lain dari kendaraan pribadi jika berhalangan. Skor persepsi ini memiliki nilai skor tengah diantara skor tertinggi dan terendah atau bisa dikatakan persepsi cukup setuju. Dari kedua pernyataan yang sudah dipaparkan, hal ini demi memberikan kontribusi serta mengoptimalkan dalam melaksanakan aktivitas kerja sehari-hari dalam mencapai tujuan instansi yang lebih baik lagi.

Berdasarkan teori Mangkunegara (2005) dalam Abdul (2014:172) menyatakan bahwa lingkungan kerja yang dimaksud antara lain uraian jabatan yang jelas, target kerja matang, pola komunikasi yang efektif, iklim kerja dan fasilitas kerja yang relatif memadai.

Penelitian ini mempunyai hasil yang sama dengan penelitian sebelumnya yang dilakukan oleh Heny Sidanti (2015) dengan judul pengaruh lingkungan kerja, disiplin kerja dan motivasi kerja terhadap kinerja pegawai negeri sipil di sekretariat DPRD kabupaten Madiun, bahwa variabel lingkungan kerja berpengaruh tidak signifikan terhadap kinerja Pegawai Negeri Sipil Kabupaten Madiun. Berdasarkan hasil penelitian di lapangan menunjukkan bahwa lingkungan kerja berpengaruh dan tidak signifikan terhadap kinerja pegawai pada kantor Kecamatan Bekasi Barat.

\section{Pengaruh disiplin kerja terhadap kinerja pegawai}

Berdasarkan hasil analisis pengujian hipotesis menunjukkan bahwa disiplin kerja berpengaruh positif dan signifikan terhadap kinerja pegawai. Apabila disiplin kerja semakin tinggi maka kinerja pegawai kantor Kecamatan Bekasi Barat semakin baik juga. Penelitian di lapangan diketahui bahwa tingkat disiplin kerja pegawai kantor Kecamatan Bekasi Barat sudah relatif baik. Hal ini dapat dilihat dari persepsi responden terhadap pernyataan-pernyataan sikap keramahan kepada masyarakat yang berkunjung atau antar sesame pegawai. Hal ini menunjukkan bahwa pegawai sudah menerapkan salahsatu aturan 5S (Sanyum, salam, sapa, sopan, santun) untuk pelayanan kepada masyarakat yang berkunjung atau antar sesama pegawai yang ada pada instansi. Dan jika hal ini sudah diterapkan oleh seluruh pegawai kantor Kecamatan Bekasi Barat maka masyarakat berkunjung untuk melakukan pemenuhan syarat administrasi negara akan merasa dirinya dihargai dan nyaman atas pelayanan 
yang diberikan oleh pegawai kantor Kecamatan Bekasi Barat. Apabila hal ini tidak dibuat dan diterapkannya aturan seperti ini mulai dari pihak kelurahan sampai kantor Kecamatan Bekasi Barat maka masyarakat yang melakukan pemenuhan syarat administrasi negara akan merasa malas berkunjung dan tidak merasa nyaman atas pelayanan yang tidak seharusnya diberikan oleh pegawai sehingga catatan atas jumlah seluruh penduduk Bekasi Barat tidak akan sesuai dengan yang ada dan hal ini akan berdampak buruk pada cerminan instansi sekaligus atas kinerja pegawai kantor Kecamatan Bekasi Barat. Maka hal ini perlu dipertahankan oleh pihak kantor Kecamatan Bekasi Barat. Sedangkan untuk persepsi cukup setuju mengenai izin keterlambatan bekerja. Persepsi seperti ini penting untuk kelancaran komunikasi antar pegawai agar pihak instansi tidak memberikan cap buruk kepada pegawai yang terlambat bekerja. Demikian pada persepsi bahwa kesungguhan pegawai dalam bekerja. Penyataan ini sesuai apa yang ada pada kondisi kantor Kecamatan Bekasi Barat bahwa kesungguhan pegawai sudah cukup baik sehingga tingkat kesalahan dalam bekerja memungkinkan sedikit. Karena kesungguhan pada kantor Kecamatan Bekasi Barat terlihat pada hasil kinerjanya walau tetap harus diperbaikki. Sehingga hal ini dapat dapat memperkecil tingkat kesalahan dalam bekerja. Skor persepsi ini memiliki nilai skor tengah diantara skor tertinggi dan terendah atau bisa dikatakan persepsi cukup setuju. Dari kedua pernyataan yang sudah dipaparkan, hal ini demi memberikan kontribusi serta mengoptimalkan dalam melaksanakan aktivitas kerja sehari-hari dalam mencapai tujuan instansi yang lebih baik lagi. Menurut Sedarmayanti (2011:222) menyatakan bahwa disiplin merupakan perbuatan tingkah laku perorangan, kelompok atau masyarakat berupa kepatuhan atau ketaatan terhadap peraturan, ketentuan, etika, norma, dan kaidah yang berlaku.

Penelitian ini mempunyai hasil yang sama dengan penelitian sebelumnya yang dilakukan Rizki Novriyanti dkk (2016) yang berjudul pengaruh kepuasan kerja dan disiplin kerja terhadap kinerja karyawan dimana pada variabel disiplin kerja berpengaruh positif dan signifikan. Berdasarkan hasil penelitian di lapangan menunjukkan bahwa disiplin kerja berpengaruh positif dan signifikan terhadap kinerja pegawai pada kantor Kecamatan Bekasi Barat.

\section{Pengaruh lingkungan kerja dan disiplin kerja terhadap kinerja pegawai}

Berdasarkan hasil pengujian hipotesis secara simultan menunjukkan bahwa lingkungan kerja dan disiplin kerja berpengaruh positif dan signifikan terhadap kinerja pegawai. Hal ini menunjukkan apabila lingkungan kerja dan disiplin kerja dikelola dengan lebih baik lagi maka akan meningkatkan kinerja pegawai pada kantor Kecamatan Bekasi Barat. Hal ini sesuai dengan penelitian terdahulu yang dilakukan oleh Yudiningsih (2016) yang meneliti mengenai pengaruh lingkungan kerja dan disiplin kerja terhadap kinerja pegawai. Hasil penelitian bahwa lingkungan kerja dan disiplin kerja memiliki pengruh positif dan signifikan terhadap kinerja pegawai di Distanak Kabupaten Buleleng. Berdasarkan hasil penelitian di lapangan menunjukkan bahwa lingkungan kerja dan disiplin kerja secara bersama-sama berpengaruh positif dan signifikan terhadap kinerja pegawai pada kantor Kecamatan Bekasi Barat. Jika ingin meningkatkan kinerja pegawai maka lingkungan kerja perlu adanya perbaikkan melalui pemantauan lanjutan dari beberapa laporan yang ada mengenai lingkungan kerja. Karena dengan lingkungan kerja yang nyaman dengan fasilitas yang memadai pegawai akan terus bersemangat untuk bekerja dan memberikan kontribusi yang baik untuk instansi dan jika hal ini sudah terpenuhi maka tidak ada lagi pegawai yang 
melanggar aturan yang ada sehingga akan memperkecil tingkat kinerja yang buruk pada pegawai.

\section{Kesimpulan dan Saran \\ Kesimpulan}

Penelitian ini bertujuan untuk menguji pengaruh variabel independen lingkungan kerja dan disiplin kerja terhadap kinerja pegawai pada kantor Kecamatan Bekasi Barat. Berdasarkan hasil penelitian dapat disimpulkan sebagai berikut :

1) Hasil pengujian hipotesis I menghasilkan persamaan regresi $Y=21,599+0,469 X_{1}$ berarti hipotesis yang menyatakan bahwa ada pengaruh positif dan tidak signifikan antara lingkungan kerja terhadap kinerja pegawai pada kantor Kecamatan Bekasi Barat. Hal ini menunjukkan lingkungan kerja masih pelu diperhatikan meski hal ini tidak dipersoalkan oleh pegawai tetapi lingkungan kerja harus tetap diperhatikan agar pegawai merasa nyaman dalam bekerja sehingga menghasilkan kinerja yang lebih baik.

2) Hasil penguji hipotesis II mengahasilkan persamaan regresi $Y=18,848+0,538 X_{2}$ berarti hipotesis yang menyatakan bahwa ada atau terdapat pengaruh positif dan signifikan antara disiplin kerja terhadap kinerja pegawai pada kantor Kecamatan Bekasi Barat . Hal ini menunjukkan bahwa displin kerja yang tinggi pada pegawai kantor Kecamatan Bekasi Barat meningkatkan kinerja pegawai.

3) Hasil pengujian hipotesis III mengahasilkan persamaan regresi $Y=13,283+0,154 X_{1}$ $0,515 \mathrm{X}_{2}$ berati hipotesis yang menyatakan bahwa ada pengaruh positif dan signifikan antara lingkungan kerja dan disiplin kerja terhadap kinerja pegawai pada kantor Kecamatan Bekasi Barat diterima. Hal ini menunjukkan bahwa secara bersama-sama lingkungan kerja dan disiplin kerja perlu diperhatikan dan perbaikkan sehingga meningkatkan kinerja pegawai. Nilai $\mathbf{R}^{2}=0,342$ yang berarti bahwa kontribusi pada lingkungan kerja dan disiplin kerja terhadap kinerja pegawai pada kantor Kecamatan Bekasi Barat sebesar 34,2\%. Hal ini menunjukkan bahwa semakin memadai lingkungan kerja dan semakin tinggi disiplin kerja yang dimiliki maka akan semakin tinggi kinerja yang diberikan.

\section{Saran}

Saran yang dapat disampaikan peneliti berdasarkan hasil penelitian sebagai berikut :

1) Berdasarkan hasil dari kuesioner yang didapat dari variabel lingkungan kerja beberapa yang memiliki skor jawaban rendah yaitu sebesar mengenai menyediaan komputer untuk pegawai agar ditambahkan untuk beberapa pegawai yang membutuhkan. Khususnya pada sub bagian tata usaha. Selain itu, mengenai penerangan lampu pada ruangan. Sebaiknya ditambah dibeberapa titik pada ruangan yang masih membutuhkan penerangan. Sehingga ruangan tidak terlihat gelap. Dan dari tanggapan dari beberapa responden yang beranggapan kalau fasilitas belum memadai agar lebih ditingkatkan lebih baik lagi sehingga pegawai akan merasa bersemangat saat bekerja dan lebih berkontribusi untuk instansi yang lebih baik dimasa yang akan datang.

2) Berdasarkan hasil dari kuesioner yang didapat dari variabel disiplin kerja memiliki skor terendah yaitu mengenai ketaatan pada peraturan. Tingkat disiplin pada kantor Kecamatan Bekasi Barat perlu diperbaikki sehingga dapat mengoptimalkan hasil kinerja yang lebih baik lagi. Selain itu instansi bisa mengelola atau memberikan reward berupa bonus-bonus yang dapat memotivasi pegawai untuk taat pada 
peraturan yang sudah ditetapkan sekaligus menambah loyalitas kinerja pegawai. Hal ini bisa dilihat dari keluar masuknya jam kerja, absensi, sikap pegawai dll.

3) Berdasarkan hasil dari kuesioner yang didapat dari variabel kinerja memiliki skor terendah yaitu mengenai penyelesaian pekerjaan sesuai target. Selama ini instansi tidak memakai target waktu penyelesaian pekerjaan sehingga lamanya pembuatan administratif. Hal ini perlu adanya penggunaan target waktu sehingga tidak ada penungguan waktu lama atau penguluran waktu yang menjadi berdampak buruk pada cerminan instansi pemerintah.

4) Bagi peneliti selanjutnya menambah variabel bebas lainnya selain lingkungan kerj dan disiplin kerja guna lebih mengetahui faktor-faktor yang juga mempengaruhi kinerja pegawai .

\section{DAFTAR PUSTAKA}

Hani T Handoko. 2009.Manajemen Personalia dan Sumber Daya Manusia. Edisi 2. Yogyakarta: BPFE.

Hasibuan, Malayu. 2011. Manajemen Sumber Daya Manusia. Edisi revisi. Jakarta: PT Bumi Aksara.

Hariyanti, Dewi, 2009, Analisis Pengaruh Budaya Organisasi, Kepuasan Kerja dan Gaya Kepemimpinan Terhadap Kinerja Karyawan Dengan Komitmen Organisasi Sebagai Variabel Intervening, Thesis, Program Studi Magister Manajemen, Pascasarjana UNDIP Semarang.

Ilmi, MakhalulSM. 2008.Teori dan Praktek Mikro Keuangan Syari'ah. Yogyakarta: UII Press.

Ismail, Iriani, 2008, Pengaruh Budaya Organisasi Terhadap Kepemimpinan dan

Kinerja Karyawan Pemerintah Kabupaten-Kabupaten di Madura, Ekuitas 12 (1) : 18-36.

Johan, Rita, 2012, Kepuasan Kerja Karyawan Dalam Lingkungan Institusi Pendidikan, Jurnal Pendidikan Penabur, 1 (1): 6-31.

Kristono, Dian, Suharmono dan Intan Ratnawati, 2011, Pengaruh Kepuasan Kerja Terhadap Kinerja Karyawan Dengan Komitmen Organisasi Sebagai Variabel Intervening (Studi Pada RSUD Tugurejo Semarang), Universitas Diponegoro.

Luthans, Fred. 2009.Perilaku Organisasi 10th. Edisi Indonesia.Yogyakarta: Penerbit ANDI.

Mas'ud,Fuad.2004. Survai Diagnosis Organisasi,Konsep \& Aplikasi Semarang: Badan Penerbit Universitas Diponegoro.

Mulyono.2009.Pengaruh Motivasi Dan Kemampuan Mnajerial Terhadap Kinerja Usaha Pedagang kaki Lima (Suatu Survey pada Pusat Perdagangan dan Wisata di Kota Surakarta).Benefit, Vol 11, No 1, Juni 2007.

Nurjanah, 2008, Pengaruh Gaya Kepemimpinan dan Budaya Organisasi Terhadap Komitmen Organisasi Dalam Meningkatkan Kinerja Karyawan (Studi Pada Biro Lingkup Departemen Pertanian), Tesis Program Pasca Sarjana Magister Manajemen Universitas Diponegoro.

Pramono, Galih.2004.Analisis Pengaruh Ketidakamanan Kerja Terhadap Kepuasan Kerja dengan Variabel Moderator Umur dan Lama Kerja (Studi Kasus Pada Karyawan Bagian Pemasaran PT. Batik Danarhadi Surakarta.Skripsi di publikasikan. 
Priyatno, Duwi, 2014, SPSS 22: Pengolahan Data Terpraktis, Edisi 1, C.V. Andi Offset, Yogyakarta.

Robbin, Stephen.2009.Perilaku Organisasi, Konsep, Kontroversi-Aplikasi.Jilid 2. Edisi Bahasa Indonesia. Jakarta : Prenhallindo.

Sugiyono. 2012. Metode Penelitian Kuantitatif dan Kalitatif dan R\&D, Bandung: Penerbit Alfabeta.

Widodo, 2011, Pengaruh Budaya Organisasi dan Motivasi Kerja Guru, Jurnal Pendidikan Penabur - No. 16/Tahun ke-10/Juni 2011.

Widodo, Untung, 2008, Analisis Pengaruh Gaya Kepemimpinan dan Kepuasan Kerja Terhadap Kinerja Bawahan (Studi Empiris Pada Perguruan Tinggi Swasta di Kota Semarang), Fokus Ekonomi 1 (2) : 92-108.

Veitsal Rivai danArifin Arvian. 2009. Islamic Leadership.Jakarta: Bumi Aksara. 